\title{
IBU RUMAH TANGGA DALAM MANAJEMEN KEUANGAN KELUARGA
}

\author{
Budi Gautama siregar \\ (Dosen Fakultas Ekonomi dan Bisnis Islam IAIN Padangsidimpuan) \\ Email: budigautamasrg20@gmail.com
}

\begin{abstract}
Abstrak
Keluarga merupakan kelompok terkecil, terpenting dan sangat mendasar dalam masyarakat dan bernegara. Salah satu permasalahan dalam keluarga yang dapat berujung kepada perceraian adalah masalah keuangan yang tidak dapat dikelola dengan baik. Tulisan ini didasarkan pada kajian-kajian teoritis dan kajian-kajian penelitian terdahulu.

Pengelolaan keuangan dalam keluarga adalah cara mengatur keuangan keluarga dengan sistematis dan cermat melalui tahap perencanaan, implementasi dan evaluasi. Ibu rumah tangga dalam pengelolaan keuangan keluarga haruslah berpikir cerdas, cermat dan tepat dalam penggunaan keuangan agar senantiasa tercipta keluarga yang baik dan mengalami pertumbuhan secara kontiniu. Dengan kemampuan ibu rumah tangga dalam pengelolaan keuangan keluarga secara tepat guna, tepat waktu, tepat tempat, tepat harga, dan tepat kualitas akan terwujudlah kesejahteraan keluarga.
\end{abstract}

Kata Kunci : Ibu Rumah Tangga, Manajemen Keuangan dan Kesejahteraan Keluarga.

\section{Abstract}

Family is the smallest, most important and very basic in society and state. One problem in the family that can lead to divorce is a financial problem that cannot be managed properly. This paper is based on theoretical studies and previous studies.

Financial management in the family is a way of managing family finances systematically and carefully through the planning, implementation and evaluation stages. Housewives in managing family finances must be smart, careful and precise in their use of finance so that a good family is always created and experiences continuous

growth. With the ability of housewives to manage family finances appropriately, on time, right place, right price, and right quality will be realized family welfare.

Keywords: Housewives, Financial Management and Family Welfare

\section{A. Pendahuluan}

Manusia merupakan makhluk sosial yang senantiasa akan berintegarasi dengan orang lain. Artinya manusia tidak akan bisa hidup tanpa adanya bantuan dari orang lain. Terjalinnya hubungan yang baik diantara sesama merupakan kebutuhan mendasar bagi setiap manusia, disamping akan kebutuhan barang dan jasa. Kebutuhan manusia akan keberadaan barang dan jasa semakin mengalami peningkatan seiring dengan tingkat kebutuhan 
yang diperoleh oleh manusia itu, tentu dalam pemenuhan kebutuhan tersebut tidak dapat dipisahkan dengan yang namanya uang. Uang mempunyai peranan yang penting dalam keberlangsungan kehidupan manusia, karena kehidupan ini menuntut kebutuhan-kebutuhan mendasar yang harus dipenuhi agar kehidupan yang selayaknya dapat terpenuhi. Adapun kebutuhan mendasar tersebut diantaranya sandang, pangan dan papan, sudah tentu dalam pemenuhannya sangat memerlukan uang.

Manusia dalam keberlangsungan kehidupannya memerlukan rumah yang merupakan tempat untuk istirahat, tempat untuk menikmati kenyamanan bersama orang-orang yang dicintai dalam kehidupan berkeluarga. Nur Eka (2012) mengatakan bahwa rumah sebagai suatu tempat tinggal untuk menjalani kehidupan serta membentuk keluarga yang saling memiliki hubungan sosial antar anggota keluarga. Keluarga merupakan kelompok terkecil, terpenting dan sangat mendasar dalam masyarakat dan bernegara (Marlina Telaumbanua \& Nugraheni, 2018). Kehidupan keluarga senantiasa dihadapkan pada persoalan-persoalan yang kompleks, sehingga diperlukan tata kelola kelola yang baik.

Mengatur keuangan merupakan aktivitas yang penting dilakukan dalam kehidupan keluarga agar keluarga tersebut dapat bertahan dan terus mengalami perkembangan. Didalam rumah tangga terdiri dari suami, istri dan anak, yang masing-masing mempunyai peranan masing-masing. Lazimnya dalam pengelolaan keuangan itu merupakan peranan besar dari seorang ibu rumah tangga, ibu rumah tangga yang mampu mengelola keuangan keluarga dengan segala keterbatasan yang ada, akan mampu membawa keluarga kearah yang baik (biasanya disebut dengan sejahtera).

Salah satu permasalahan dalam keluarga yang dapat berujung kepada perceraian adalah masalah keuangan yang tidak dapat dikelola dengan baik. Banyak masalah keuangan yang diperketat, pengeluaran yang tidak jelas bahkan pendapat yang berbeda mengenai penggunaan uang sehingga menimbulkan 


\section{Jurnal Kajian Gender dan Anak}

Vol. 03 No. 1 Juni 2019

Pusat Studi Gender dan Anak IAIN Padangsidimpuan

perasaan sakit hati yang berujung pada pertengkaran dalam rumah tangga (Handayani, 2013).

Merujuk data Badan Peradilan Agama (Badilag) Mahkamah Agung, tingkat perceraian keluarga Indonesia dari waktu ke waktu memang semakin meningkat. Pasca reformasi politik di Indonesia tahun 1998, tingkat perceraian keluarga Indonesia terus mengalami peningkatan. Data tahun 2016, angka perceraian mencapai $19,9 \%$ dari 1,8 juta peristiwa. Sementara data 2017, angkanya mencapai $18,8 \%$ dari 1,9 juta peristiwa. Jika merujuk data 2017 , maka ada lebih 357 ribu pasang keluarga yang bercerai tahun itu. Fakta tersebut menunjukkan bahwa gambaran kasus perceraian yang terjadi berasal dari istri menggugat cerai suami yang disebabkan berbagai faktor, diantaranya faktor pernikahan usia dini, permasalahan keuangan keluarga, dll.

Pada dasarnya pengelolaan keuangan keluarga tidak pernah kita terima pada saat menjalani pendidikan formal, namun dari pelajaran tentang manajemen keuangan perusahaan, negara, yayasan tersebut dapat kita jadikan pengalaman dan menjadi dasar dalam melakukan pengelolaan keuangan dalam keluarga. Biasanya ibu rumah tangga terlatih dalam pengelolaan keuangan keluarga didasarkan pada pengalaman yang sudah dijalankannya sendiri dan juga pemahaman agama yang kuat.

Melalui peran istri yang strategis tersebut dalam keluarga akan dapat mempengaruhi tingkat kesejahteraan keluarga. Apalagi zaman sekarang ini, istri dituntut untuk lebih kreatif, ulet, tekun dan sabar dalam mencapai keluarga sejahtera, karena seorang istri mempunyai tugas yang sangat kompleks dalam keluarga disamping sebagai pengurus rumah tangga, istri juga harus mampu mengelola keuangan keluarga demi menjaga kestabilan dan pertumbuhan ekonomi keluarga tersebut.

\section{B. Metode Penelitian}

Pembahasan tulisan ini didasarkan pada kajian secara teoritis dan kajian-kajian penelitian terdahulu, selanjutnya dideskripsikan sesuai dengan 
fenomena yang terdapat dalam penelitian ini. Teori yang dibahas dalam penelitian ini adalah manajemen keuangan, manajemen keuangan keluarga, keluarga sejahtera. Hasil/temuan penelitian didasarkan pada kajian penelitian terdahulu tentang peran perempuan dalam pengelolaan keuangan menuju keluarga yang sejahtera.

\section{Kajian Teori \\ Manajemen keuangan}

Dalam menjalankan kehidupan yang berimplementasi dengan pelaksanaan aktivitas, tentunya harus diawali dengan proses manajemen sehingga dapat tercapai tujuan yang dimaksud secara masimal. Manajemen pada umumnya adalah suatu proses yang terdiri atas planning, organizing, actuating dan controlling yang dilakukan dalam mencapai tujuan yang telah ditentukan dengan mengerahkan seluruh sumber daya yang tersedia (Herujito, 2001). Selanjutnya pendapat George Terry mengemukakan bahwa manajemen itu adalah pencapaian tujuan yang ditetapkan terlebih dahulu dengan mengarahkan dan menggunakan orang lain. Sedangkan menurut Siagian dalam bukunya Hames S. F. Stoner menyebutkan bahwa manajemen adalah tujuan yang ingin dicapai dengan mengarahkan orang lain yaitu dengan membimbing dan mengawasinya agar bersedia melakukan kegiatan yang telah ditetapkan (Rodhiyah, 2012).

Sedangkan keuangan pasti akan dibutuhkan oleh setiap perusahaaan, organisasi, individu maupun keluarga dalam memperlancar seluruh kegiatan operasionalnya. Sundjaja \& Berlian (2002: 34) menyebutkan bahwa keuangan merupakan suatu ilmu dan seni yang digunakan untuk mengelola uang dalam mempengaruhi kehidupan setiap orang/ organisasi. Keuangan berhubungan dengan proses, lembaga, pasar dan instrumen yang terlibat dalam transfer uang diantara perorangan maupun antar organisasi/ perusahaan. Martono \& Harjito (220: 4) mendefinisikan manajemen keuangan yaitu sebagai aktivitas perusahaan yang berhubungan dengan 


\section{Jurnal Kajian Gender dan Anak}

Vol. 03 No. 1 Juni 2019

Pusat Studi Gender dan Anak IAIN Padangsidimpuan

bagaimana memperoleh dana, menggunakan dana dan mengelolanya sesuai dengan tujuan perusahaan secara menyeluruh.

Berdasarkan penjelasan diatas maka dapat disimpulkan bahwa manajemen keuangan merupakan fungsi yang sangat strategis dalam pengelolaan keuangan baik yang dilakukan oleh individu, perusahaan/ organisasi maupun pemerintah.

\section{Manajemen Keuangan Keluarga}

Manajemen keuangan pada umumnya merupakan suatu kegiatan pengelolaan sumber daya keuangan perusahaan mulai dari bagaimana pendanaan perusahaan, bagaimana pengelolaannya serta apa keuntungan yang diperoleh yang kemudian akan dibagikan kepada pemilik perusahaan. Dalam tulisan ini akan dikaitkan dengan manajemen keuangan dalam keluarga. Hal ini sejalan dengan pendapat Sudjana menyatakan bahwa manajemen keuangan tidak hanya penting untuk perusahaan saja tetapi pengetahuan akan manajemen keuangan juga penting untuk diterapkan dalam lingkungan kehidupan keluarga (Sundjaja et al., 2011). Keluarga merupakan kumpulan dari ayah, ibu dan anak dalam mengarungi perjalanan kehidupan yang didasari atas tujuan bersama. Kehidupan dalam keluarga merupakan sebuah media yang menempati posisi penting dalam mewujudkan kesinambungan hidup. Jeffa Leibo mengatakan bahwa keluarga merupakan bentuk tingkah laku yang berhubungan dengan fungsi-fungsi untuk melahirkan/ menurunkan keturunan dan berfungsi sebagai kelengkapan masyarakat dalam membentuk warga yang mencerminkan identitas setempat (Rahmah, 2014).

Keluarga berfungsi pada seluruh aspek dalam kehidupan, diantaranya fungsi biologis, fungsi pemeliharaan, fungsi ekonomi, fungsi keagamaan, fungsi sosial, dan sebagainya. Kompleksitas dari fungsi keluarga tersebut mengisyaratkan bahwa keluarga merupakan lembaga sosial yang sangat berarti dalam kehidupan manusia. Dalam perjalanan sebuah keluarga tentu 


\section{Ibu Rumah Tangga Dalam Manajemen.... Budi Gautama siregar budigautamasrg20@gmail.com}

sangat dipengaruhi oleh masalah keuangan. Dengan pengelolaan keuangan yang baik maka akan tercipta pemenuhan kebutuhan hidup keluarga yang baik pula. Dan mengatur keuangan sesungguhnya tidak hanya mengatur uang masuk dan keluar saja yang harus dipikirkan dalam memenuhi kebutuhan dasar manusia, namun juga harus dipikirkan dana mana yang akan memenuhi kebutuhan ketika memasuki usia non produktif untuk masa yang akan datang.

Jadi dapat disimpulkan bahwa managemen keuangan keluarga adalah suatu seni dalam mengelola keuangan keluarga melalui orang lain untuk mencapai tujuan yang bermanfaat, sehingga keluarga tersebut menjadi keluarga yang sejahtera. Management keuangan keluarga merupakan keharusan yang tidak bisa di tawar lagi, karena pengelolaan keuangan keluarga memiliki implikasi yang lebih luas sebab yang terlibat bukan hanya diri sendiri, tetapi istri/suami, anak-anak bahkan orang tua maupun mertua (Rodhiyah, 2012).

\section{Kesejahteraan Keluarga}

Kesejahteraan keluarga merupakan idaman semua orang yang sudah berumah tangga, karena keluarga memiliki peranan yang sangat penting dalam kehidupan. Keluarga merupakan dasar untuk menempuh kondisi yang sedang kita hadapi dalam berintegrasi dilingkungan yang lainnya. Definisi kesejahteraan menurut Kamus Besar Bahasa Indonesia adalah "hal atau keadaan sejahtera, aman, selamat dan tentram" (Depdiknas, 2001:1011).

Dalam mewujudkan keluarga sejahtera, maka suami, istri, anak harus dapat memahami dan melaksanakan peranan serta fungsi masing-masing sesuai kedudukannya. Dengan terciptanya keluarga sejahtera, maka akan dapat mengembangkan kualitas keluarga yang di menumbuhkan rasa aman, tentram dan memiliki harapan untuk masa dengan yang lebih baik.

Kesejahteraan keluarga adalah kondisi yang harmonis, tentram serta terpenuhinya kebutuhan jasmani dan sosial bagi anggota keluarga tanpa 


\section{Jurnal Kajian Gender dan Anak}

Vol. 03 No. 1 Juni 2019

Pusat Studi Gender dan Anak IAIN Padangsidimpuan

mengalami hambatan yang serius, dan dalam menghadapi masalah yang terjadi dalam keluarga akan mudah untuk dilewati secara bersama oleh anggota keluarga sehingga standar kehidupan keluarga dapat terwujud (Soetjipto, 1992). Kesejahteraan keluarga bukanlah hanya menyangkut kemakmuran dari satu sudut pandang tertentu melainkan juga harus menujukkan secara keseluruhan aspek dalam kehidupan keluarga tersebut sehingga tercipta keselamatan dan ketentraman hidup.

Mongid (1995:10), mengatakan bahwa kesejahteraan keluarga adalah suatu kondisi dinamis keluarga dimana terpenuhi semua kebutuhan fisik materil, mental spiritual, dan sosial yang memungkinkan keluarga dapat hidup wajar sesuai dengan lingkungannya serta memungkinkan anak-anak tumbuh kembang dan memperoleh perlindungan yang diperlukan untuk membentuk sikap mental dan kepribadian yang matang sebagai sumber daya manusia yang berkualitas. Keluarga sejahtera merupakan suatu keadaan dimana sifatnya yang dinamis dalam memenuhi kebutuhan primer dan sekunder suatu keluarga.

Pada umumnya kesejahteraan keluarga dipengaruhi oleh faktor internal dan eksternal keluarga. Faktor internal keluarga terdiri dari jumlah anggota keluarga, tempat tinggal, kondisi sosial keluarga, kondisi ekonomi keluarga. Sedangkan faktor eksternal keluarga terdiri dari faktor manusia diluar internal keluarga (seperti iri hati, fitnah dari tetangga, ancaman fisik dan pelanggaran norma), faktor alam seperti musibah bencana alam, kerusakan lingkungan hidup, dll (Marlina Telaumbanua \& Nugraheni, 2018).

\section{Pembahasan}

\section{Prinsip dan Urgensi Manajemen Keuangan Keluarga}

Untuk mencapai keluarga yang sejahtera, tentu masing-masing anggota keluarga harus dapat melaksanakan fungsi dan perannya dengan baik serta memiliki persepsi dan pengertian yang sama tentang prinsip dari 
pengelolaan keuangan rumah tangga. Prinsip-prinsip dasar dalam pengelolaan keuangan rumah tangga muslim yaitu:

a. Berupaya mencari nafkah yang halal.

Setiap anggota keluarga (Suami, istri dan anak) harus saling saling mengingatkan dan mengontrol apa yang mereka dapat dalam rumah tangga.

b. Hemat dan ekonomis

Salah satu langkah hebat orang tua dalam mendidik anak adalah berhemat dan tidak konsumtif untuk hal-hal yang tidak diperlukan. Di sini harus ada proses komunikasi, komitmen bersama dan contoh nyata dari orang tua kepada anak.

c. Membiasakan diri menabung untuk dunia akhirat.

Setiap anggota keluarga harus sepakat untuk selalu menabung dan bersedekah dalam kondisi apapun (Kusumawati, 2011).

Menurut ajaran agama Islam secara fitrah kewajiban dalam memberi nafkah/ kebutuhan merupakan tanggung jawab suami. Namun, dalam prakteknya harus dilakukan keterbukaan antara pasangan keluarga tentang dari mana dan berapa besar penghasilan yang diperoleh oleh suami, sehingga ibu rumah tangga akan tergerak untuk berusaha mengelola pendapatan suami sebaik mungkin dalam memenuhi segala kebutuhan keluarga. Komitmen juga merupakan hal sangat penting sekali dilakukan antara suami dan istri dalam pengelolaan keuangan agar tidak terjadi miskomunikasi yang dapat menimbulkan pertengkaran dalam rumah tangga tersebut.

Keluarga adalah organisasi terkecil tetapi berdampak besar bagi seluruh anggotanya, diantaranya adalah dalam pembentukan karakter sadar dan bijak dalam pengelolaan keuangan. Hampir seluruh anggota keluarga baik ibu rumah tangga, suami dan anak pasti menghadapi yang permasalahan keuangan. Karena uang sangat dibutuhkan untuk menjalani kehidupan. Uang diperlukan untuk membeli kebutuhan sehari-hari, termasuk makanan, 


\section{Jurnal Kajian Gender dan Anak}

Vol. 03 No. 1 Juni 2019

Pusat Studi Gender dan Anak IAIN Padangsidimpuan

pakaian, perumahan, pendidikan, dan biaya pengobatan, dll. Penggunaan uang harus diatur secara bijak dan terorganisir, mengatur keuangan bukan berarti menjadi pelit tetapi pengeluarannya dapat diukur berdasarkan manfaat dan tingkat kebutuhannya.

Manajemen/ Pengelolaan keuangan dalam keluarga adalah cara mengatur keuangan keluarga dengan sistematis dan cermat melalui tahap perencanaan, implementasi dan evaluasi. Besar kecilnya pendapatan dalam keluarga memang menjadi salah satu faktor dalam memenuhi kebutuhan keluarga, namun yang paling penting adalah ketrampilan dalam mengelola keuangan keluarga itu sendiri. Tanpa pengetahuan akan manajemen keuangan (perencanaan keuangan keluarga, implementasi dan evalusasi), maka kehidupan keluarga tersebut dapat dipastikan akan mengalami permasalahan yang pada akhirnya dapat mengganggu ketentraman dan kesejahteraan keluarga. Kusumawati, (2011) mengatakan Dalam pengelolaan keuangan, sebelumnya kita juga harus mempunyai suatu perencanaan anggaran supaya di dalam penggunaannya tidak melenceng dari kebutuhankebutuhan yang ada. Yang dimaksud dengan anggaran adalah suatu rencana yang disusun secara sistematis yang meliputi seluruh kegiatan perusahaan (rumah tangga), yang dinyatakan dalam unit satuan moneter dan berlaku dalam jangka waktu tertentu yang akan datang.

Manajemen keuangan keluarga bukanlah soal yang mudah dalam prakteknya sehari-hari, hal ini disebabkan karena kompleksnya tingkat kebutuhan yang akan diperlukan. Pendapatan keluarga yang banyak akan dapat menyebabkan kebutuhan keluarga tidak terpenuhi apabila tidak dikelola dengan baik demikian juga sebaliknya. Untuk itu, sangat diperlukan pengetahuan dan ketrampilan manajemen keuangan dalam keluarga. Pada umumnya setiap kelurga memiliki ketrampilan yang berbeda dalam memenuhi kebutuhannya sehari-hari baik kebutuhan material maupun immaterial. 
Dengan manajemen keuangan keluarga yang baik, maka akan teratasi segala keterbatasan yang ada, artinya uang yang terbatas akan dapat dikendalikan penggunaannya dengan tepat sehingga tercipta kesejahteraan keluarga. Bagi keluarga dengan tingkat pendapatan yang pas-pasan, manajemen keuangan sangat penting dimiliki, karena dengan uang yang terbatas tersebut sangat sedikit jenis kebutuhan yang dapat dipenuhi. Demikian pula bagi keluarga yang berkecukupan, manajemen keuangan juga sangat penting dimiliki, karena keinginan itu sifatnya tidak terbatas dan sangat memungkinkan untuk terjadinya pengeluaran yang tidak terkontrol (Nofianti \& Denziana, 2018).

Sistem manajemen keuangan keluarga umumnya dapat dilakukan sesuai dengan proses manajemen yaitu adanya perencanaan yang matang, implementasi yang ketat, dan evaluasi yang terukur. Manullang dalam bukunya pengantar ekonomi perusahaan menyebutkan bahwa manajemen keuangan keluarga dibagi dalam tiga langkah, yaitu:

a. Perencanaan pengeluaran keuangan

Langkah pertama yang dilakukan dalam manajemen keuangan keluarga adalah dengan mendata seluruh pendapatan yang diperoleh keluarga, hal ini diperlukan agar dapat mengetahui seberapa besarnya pendapatan keluarga dalam satu bulan. Setelah dicatat dan diketahui total pendapatan, selanjutnya membuat daftar pengeluaran rutin keluarga dalam satu bulan, daftar pengeluaran tidak rutin dengan skala prioritas (urutkan prioritas pemenuhannya). Rencana keuangan yang realistis membantu bersikap obyektif soal pengeluaran yang berlebihan. Tak perlu terlalu ideal, sehingga lupa kebutuhan diri sendiri. Yang penting, anggarkan jumlah yang realistis dan harus patuh dengan anggaran tersebut (Handayani, 2013). Selanjutnya Pangeran, (2011) juga menyebutkan bahwa rumah tangga memandang pentingnya menganggarkan uang secara baik dan digunakan dengan hati-hati. 


\section{Jurnal Kajian Gender dan Anak}

Vol. 03 No. 1 Juni 2019

Pusat Studi Gender dan Anak IAIN Padangsidimpuan

Langkah kedua setelah diketahui total pendapatan dalam sebulan dan total pengeluaran baik yang rutin maupun tidak rutin kemudian jumlahkan seluruh pengeluaran dan bandingkan dengan total pendapatan, apabila jumlah rencana pengeluaran lebih besar dari pendapatan maka harus dilakukan seleksi kembali terhadap pengeluaran tidak rutin untuk mengetahui pengeluaran mana yang pemenuhannya dapat ditunda.

b. Implementasi manajemen keuangan keluarga

Dalam implementasi/ penerapan rencana keuangan keluarga yang telah kita susun, dapat dilakukan dengan berbagai model/ sistem, yaitu:

a) Sistem amplop

Sistem amplop digunakan sebagai tempat untuk menyimpan sementara uang kita sesuai dengan kebutuhan yang telah direncanakan sebelumnya. Jadi, uang dibagi berdasarkan amplop yang telah ditentukan dan dituliskan peruntukannya, hal ini berarti jumlah amplop sesuai jumlah kebutuhan yang telah direncanakan dan disetujui sebelumnya.

b) Sistem buku kas

Sistem buku kas yang dimaksud dalam hal ini adalah tidaklah selengkap yang ada dalam pelajaran akuntansi, namun dibuat sesuai dengan kemampuan kita dan sesederhana mungkin. Hal ini gunanya sebagai panduan bagi kita untuk mengetahui perjalanan pendapatan dan pengeluaran yang sudah direncakanan.

c) Sistem kas keluarga

Sistem kas keluarga merupakan sistem pembukuan keuangan yang menekankan pada pembagian pengeluaran menjadi kelompokkelompok : pengeluaran tetap, harian, dan tak terduga. Semua dicatat secara rinci dalam buku dan setiap jenis pengeluaran dijumlah lalu ditotal dengan pengeluaran jenis lain.

d) Sistem kas harian 


\section{Ibu Rumah Tangga Dalam Manajemen.... \\ Budi Gautama siregar \\ budigautamasrg20@gmail.com}

Sistem pembukuan keuangan yang menekankan pada catatan pengeluaran setiap hari. Sistem ini biasa berhasil bila dianut oleh orang yang rajin mencatat apapun yang dikeluarkan setiap hari tanpa malas untuk menulis, meskipun pengeluaran dalam jumlah kecil. Bagi ibu rumahtangga yang menggunakan sistem ini harus secara sabar dan telaten menulis, sebab ketinggalan satu hari saja akan mengacaukan pembukuan berikutnya, sebab daya ingat orang memang terbatas.

c. Evaluasi Keuangan Keluarga

Dalam ilmu manajemen kegiatan evaluasi merupakan kegiatan yang berpengaruh terhadap perencanaan dan implementasi yang sudah dilakukan sehingga dapat diketahui kekurangan dari perencanaan dan implementasi. Hasil dari evaluasi tersebut akan menjadi informasi dalam melakukan kegiatan perencanaan berikutnya.

Kriteria yang digunakan untuk menilai pengelolaan / manajemen keuangan dapat berpedoman pada 5 hal, yaitu : tepat guna, tepat waktu, tepat tempat, tepat harga, dan tepat kualitas. Penilaian akan berhasil bila dilakukan secara kontinu, menyeluruh, objektif, sistematis, dan ada kerjasama diantara semua anggota keluarga. Penilaian dapat dilakukan secara sebagian atau secara keseluruhan (Nofianti \& Denziana, 2018).

\section{Peran Ibu Rumah Tangga Dalam Menuju Keluarga Sejahtera}

Pintu utama dalam membentuk sebuah keluarga adalah dengan proses pernikahan. Kalau diumpamakan keluarga tersebut sebuah organisasi dimana didalamnya terdapat pimpinan dan anggota yang memiliki peran serta tugas masing-masing. Dalam pembagian tanggungjawab keluarga sangat diperlukan komunikasi yang baik terutama komunikasi antara suami dan istri. Komunikasi yang baik adalah kunci yang paling efektif dalam menjalankan kehidupan keluarga menuju sejahtera. Demikian halnya tentang urusan keuangan, berapapun pendapatan ataupun pengeluaran yang 


\section{Jurnal Kajian Gender dan Anak}

Vol. 03 No. 1 Juni 2019

Pusat Studi Gender dan Anak IAIN Padangsidimpuan

digunakan baik pengeluaran untuk pribadi maupun untuk kebutuhan bersama harusnya tetap terbuka.

Seorang ibu dalam rumah tangga mempunyai peranan yang sangat kompleks, atau dapat dikatakan bahwa ibu sangat mempunyai peranan yang sangat besar dalam mewujudkan keluarga bahagia, penuh kehangatan dan kasih sayang. Setiap rumah tangga mempunyai strategi keuangannya masing-masing dalam rangka mempertahankan kelangsungan hidup anggota keluarganya. Setiap rumah tangga memiliki manajemen keuangan rumah tangga dan kebanyakan ibu rumah tangga bertindak sebagai manajer, bagaimana cara masing-masing rumah tangga mengatur keuangan akan berbeda-beda. Keuangan keluarga diatur sepenuhnya oleh ibu rumah tangga, suami akan menyerahkan seluruh penghasilannya kepada istri untuk dikelola, dipihak lain keuangan keluarga diatur sepenuhnya oleh kepala keluarga, istri hanya akan mendapatkan uang untuk belanja keperluan rumah tangga sehari-hari. Dan adapun alternatif lain, keuangan keluarga diatur bersama, biasanya cara ini berlaku bagi suami istri yang bekerja (Setiowati, 2016).

Kehidupan keluarga sangatlah kompleks sehingga sangat penting pengaturan dan perencanaan keuangan di dalam keluarga dimana kita bisa menemukan suatu kinerja praktek dalam pengembangan akuntansi secara transparansi dan akuntabilitas di dalam pengelolan keuangan keluarga untuk kebutuhan sehari-hari.

Ibu rumah tangga yang berperan sebagai manajer keuangannya keluarga haruslah berpikir cerdas dalam penggunaan keuangannya agar senantiasa tercipta keluarga yang baik dan mengalami pertumbuhan secara kontiniu. Pada umumnya manajemen keuangan dalam lingkungan apapun termasuk dalam keluarga terdiri 3 aktivitas yaitu aktivitas penggunaan dana, aktivitas pengelolaan dana dan aktivitas pengelolaan aktiva (Handayani, 2013). Jadi ibu rumah tangga harus dituntut mampu melakukan ketiga aktivitas tersebut dalam mengelola keuangan dalam keluarganya. 
Handayani, (2013) menyebutkan beberapa cara yang harus ditempuh oleh ibu rumah tangga dalam mengelola keuangan, yaitu:

a) Memahami portofolio keuangan keluarga;

b) Menyusun rencana keuangan keluarga yang terdiri dari pendapatan, pengeluaran rutin, pengeluaran tidak rutin dan pengeluaran yang tidak terduga;

c) Membedakan antara kebutuhan keluarga dan keinginan;

d) Menghindari hutang untuk konsumtif dan gaya hidup yang berlebihan;

e) Meminimalkan belanja konsumtif;

f) Menetapkan tujuan atau cita-cita finansial baik jangka pendek, menengah maupun jangka panjang;

g) Mengupayakan untuk menabung

h) Melakukan investasi untuk menambah pendapatan keluarga.

Kesejahteraan keluarga sangat besar dipengaruhi oleh kecerdasan ibu tangga termasuk dalam hal pengelolaan keuangan. Sekalipun ibu rumah tangga sudah menyusun perencanaan keuangan keluarga namun harus tetap melakukan komunikasi yang baik dengan suami agar tidak terjadi keributan yang dapat berujung fatal.

Kesejahteraan keluarga tidak ditandai dengan besarnya pendapatan keluarga, akan tetapi sangat tergantung bagaimana ibu rumah tangga dalam mengelolanya untuk kesejaterahan keluarga. Untuk itu, ibu rumah tangga harus cerdas dalam mengatur pengeluaran dengan membuat skala prioritas dalam pemenuhannya. Dengan keluarga sejahtera, maka akan tercipta kehidupan yang nyaman, tentram, saling mengasihi sehingga anak akan dapat tumbuh dengan baik dan pada akhirnya akan terciptalah generasi penerus yang berkualitas.

\section{Kesimpulan}

Manajemen keuangan keluarga merupakan suatu seni yang harus dimiliki oleh seorang ibu rumah tangga sebagai pemegang keuangan 


\section{Jurnal Kajian Gender dan Anak}

Vol. 03 No. 1 Juni 2019

Pusat Studi Gender dan Anak IAIN Padangsidimpuan

keluarga. Melalui pengelolaan keuangan yang cerdas, baik dan cermat maka pendapatan yang diperoleh keluarga diharapkan dapat digunakan tepat guna, tepat waktu, tepat tempat, tepat harga, dan tepat kualitas. Pengelolaan keuangan keluarga umumnya dapat dilakukan sesuai dengan proses manajemen yaitu adanya perencanaan yang matang, implementasi yang ketat, dan evaluasi yang terukur.

Kesejahteraan keluarga adalah kondisi yang harmonis, tentram serta terpenuhinya kebutuhan jasmani dan sosial bagi anggota keluarga tanpa mengalami hambatan yang serius, dan dalam menghadapi masalah yang terjadi dalam keluarga akan mudah untuk dilewati secara bersama oleh anggota keluarga sehingga standar kehidupan keluarga dapat terwujud. Dengan kemampuan ibu rumah tangga dengan melakukan manajemen keuangan tepat guna, tepat waktu, tepat tempat, tepat harga, dan tepat kualitas akan terwujudlah kesejahteraan keluarga. 


\section{Ibu Rumah Tangga Dalam Manajemen.... \\ Budi Gautama siregar \\ budigautamasrg20@gmail.com}

\section{DAFTAR PUSTAKA}

Depdiknas .2001. Kamus Besar Bahasa Indonesia.Jakarta ;Balai Pustaka.

Handayani, N. (2013). Cara Sederhana Mengelola Keuangan Keluarga. Jurnal Keluarga Sejahtera, 11(22), 29-34.

Herujito, Y. M. (2001). Dasar-dasar manajemen. Jakarta, ID: Grasindo

James A.F. Stoner, Manajement Jilid I \& II Prenhallindo, Jakarta, 1996 Rhenald Kasali, dalam Elvyn G. Masassya, Cara Cerdas Mengelola Investasi Keluarga, Gramedia, Jakarta, 2004.

Kusumawati, D. (2011). Pengelolaan Keuangan dalam Keluarga dari Sudut Pandang Islam. Gema Eksos, 6(2), 175-186.

Marlina Telaumbanua, M., \& Nugraheni, M. (2018). Peran Ibu Rumah Tangga Dalam Meningkatkan Kesejahteraan Keluarga. Sosio Informa (Vol. 4). https://doi.org/10.33007/inf.v4i2.1474

Martono SU dan D. Agus Harjito, 2002, Manajemen Keuangan, Edisi Pertama, Cetakan Kedua, Yogyakarta : Ekorisia.

Mongid, A. 1995. Gerakan Pembangunan Keluarga Sejahtera. Jakarta: BKKBN.

Nofianti, L., \& Denziana, A. (2018). Manajemen Keuangan Keluarga. Marwah: Jurnal Perempuan, Agama Dan Jender, 9(2), 192.

Pangeran, P. (2011). Sikap Keuangan Rumah Tangga Desa Pada. Jrak, 8(1), $35-50$.

Rahmah, S. (2014). Pola Pengelolaan Keuangan Keluarga Pada Ibu Rumah Tangga ( Studi Pada Ibu Rumah Tangga Yang Bekerja Sebagai Cleaning Service. Marwah, XIII(1). 


\section{Jurnal Kajian Gender dan Anak}

Vol. 03 No. 1 Juni 2019

Pusat Studi Gender dan Anak IAIN Padangsidimpuan

Rodhiyah. (2012). Manajemen Keuangan Keluarga Guna Menuju Keluarga Sejahtera. FORUM: Majalah Pengembangan Ilmu Sosial, (1), 28-33.

Setiowati, N. E. (2016). PEREMPUAN, STRATEGI NAFKAH DAN AKUNTANSI RUMAH TANGGA. Perbankan Syariah Fakultas Syariah Dan Ekonomi Islam IAIN Syekh Nurjati Cirebon, 298-304.

Sundjaja Ridwan S. dan Inge Barlian. 2003. Manajemen Keuangan 1, Edisi kelima. Jakarta: Literata Lintas Media

Sundjaja, R. S., Gomulia, B., Sundjaja, D. P., Oriana, F., Meilinda, I. B., \& Dewi, V. I. (2011). Pola Gaya Hidup dalam Keuangan Keluarga (Studi Kasus:Unit Kerja Institusi Pendidikan Swasta di Bandung). Bina Ekonomi Majalah Ilmiah Fakultas EKonomi Unpar, 15(2).

Soetjipto, 1992. Pendidikan Kesejahteraan Keluarga. Semarang: Satya Wacana Press. 